\title{
Methylenetetrahydrofolate reductase (MTHFR) A1298C polymorphism and risk of lung cancer
}

\author{
Vandana Rai \\ Department of Biotechnology, VBS Purvanchal University, Jaunpur-222003, UP, India
}

\begin{abstract}
:
Recent epidemiological studies have reported association between methylenetetrahydrofolate reductase (MTHFR) gene polymorphisms and lung cancer. The aim of the present study to perform a metaanalysis of published studies to validate the association between MTHFR A1298C polymorphism and risk of lung cancer.PubMed, Springer Link, Science Direct and Google Scholar databases were searched for eligible studies. Of the 78 initially identified studies, 11 case-control studies with 5,996 patients and 7,404 healthy controls were finally included in the present meta-analysis. Odds ratios (ORs) with 95\% confidence intervals (CIs) were estimated to assess the association, and all statistical analyses were performed using MIX software (version 1.7).

No statistically significant associations were found between the MTHFR A1298C polymorphism and lung cancer risk in the additive/ allele contrast, co-dominant/heterozygote, homozygote, dominant and recessive genetic models $(\mathrm{C}$ vs. $\mathrm{A}: \mathrm{OR}=0.95,95 \% \mathrm{CI}=0.83-1.08 ; \mathrm{CC}$ vs. $\mathrm{AA}: \mathrm{OR}=1.13,95 \% \mathrm{CI}=$ 0.83-1.5; $\mathrm{AC}$ vs. $\mathrm{AA}: \mathrm{OR}=0.86,95 \% \mathrm{CI}=0.70-1.02$; $\mathrm{AC}+\mathrm{CC}$ vs. $\mathrm{AA}: \mathrm{OR}=0.89,95 \% \mathrm{CI}=0.75-1.05$; $\mathrm{CC}$ vs. $\mathrm{AA}+\mathrm{AC}: \mathrm{OR}=1.20,95 \% \mathrm{CI}=0.89-1.40$ ). Significant heterogeneity between individual studies was evident in all five models. In conclusion, present meta-analysis results indicated that there is no significant association between MTHFR A1298C polymorphism and risk of lung cancer.
\end{abstract}

\section{Key Words:}

Methylenetetrahydrofolate reductase, Lung Cancer, MTHFR, A1298C, Meta-analysis, Polymorphism

\section{Introduction:}

Lung cancer is the leading cause of cancer-related death worldwide. The incidence and mortality of lung cancer have been significantly and constantly increasing (Parkin et al.,2002; Jemal et al.,2007; Cui et al.,2011). Lung cancer is still the common cancer in men worldwide (1.1 million cases, $16.5 \%$ of the total), with high rates in Central-eastern and Southern Europe, Northern America and Eastern Asia. Very low rates are still estimated in Middle and Western Africa (2.8 and 3.1 per 100,000, respectively)(Ferlay et al.,2010). Lung cancer is a common disease that results from a complex interplay of genetic and environmental risk factors (Kiyohara et al.,2011). Many epidemiological studies have provided evidence that high consumption of vegetables and fruits is associated with a reduced risk of lung cancer (Suzuki et al.,2007). Folate is one of the constituents found in vegetables and fruits, and dietary folate may be one of the micronutrients that provide protection against lung carcinogenesis (Suzuki et al.,2007).

5,10-methyl enetetrahydrofolate reductase (MTHFR) gene (OMIM*607093; chromosome 1p36.3) is an important enzyme involved in folate metabolism and is thought to influence DNA methylation and nucleotide synthesis. The low enzymatic activity of the MTHFR C677T genotypic variant is associated with DNA hypomethylation, which may induce genomic instability or randomly reactivates the protooncogenes to oncogenes(Ozen et al.,2013). Two common and clinically important polymorphisms (C677T and A1298C) identified in the MTHFR gene (Frosst et al.,1995; Weisberg et al.,1998). Frequency of C677T polymorphism varies greatly worldwide (Rai et al.,2010,2012; Yadav et al.,2017). Substitution at nucleotide 1,298 (exon 7) results in an amino acid substitution of glutamate for alanine at codon 429 (van der Put et al.,1998). A1298C (glutamate to alanine) polymorphism, has been associated with decreased enzyme activity (40\%), although to a lesser extent than C677T (Weisberg et al.,1998). A1298C allele frequency differs greatly in various ethnic groups of the world.

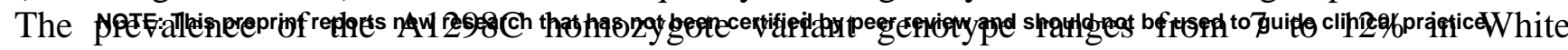


populations from North America and Europe. Lower frequencies have been reported in Hispanics (4 to $5 \%$ ), Chinese (1 to $4 \%$ ) and Asian populations (1 to 4\%)( Botto and Yang,2000; Robien and Ulrich, 2003). To date, several studies have shown that the MTHFR A1298C polymorphism are associated with either increased or decreased risk of lung cancer, whereas others observed no association between the MTHFR A1298C genotype and lung cancer. Small sample size, various ethnic groups, diet, environment, and methodologies might be responsible for the discrepancy. Therefore, a meta-analysis is required to evaluate MTHFR A1298C polymorphism as risk factor for lung cancer.

\section{Methods:}

Present meta-analysis was conducted according to Moose guidelines (Stroup et al.,2000). PubMed, Google Scholar, Springer Link and Elsevier database s were searched for eligible studies. The last search was conducted on December 20, 2016. Following terms were used for search: 'Methylenetertahydrofolate reductase', 'MTHFR', 'A1298C', and 'lung cancer'.

\section{Inclusion criteria:}

The following inclusion criteria were used : (i) study should be case control and should evaluate MTFR A1298C polymorphism, (ii) study should be published, (iii) study should be in English language, (iv) study should contained sufficient data to calculate odds ratio (OR) with $95 \%$ confidence interval (CI), and (v)study should not contained duplicated data.

\section{Data Extraction:}

The following information was extracted from each included study: first author's name, journal name, year of publication, country name, number of cases and controls. Number of alleles or genotypes in both cases and controls were extracted or calculated from published data to recalculate ORs.

\section{Statistical analysis:}

The associations were indicated as a pooled odds ratio (OR) with the corresponding $95 \%$ confidence interval (CI). The heterogeneity between studies was tested using the Q-statistic, which is a weighted sum of the squares of the deviations of individual study OR estimates from the overall estimate (Cochran,1954). When the ORs are homogeneous, $\mathrm{Q}$ follows a chi-squared distribution with $\mathrm{r}-1$ ( $\mathrm{r}$ is the number of studies) degrees of freedom (df). When $\mathrm{P}<0.05$ then the heterogeneity was considered to be statistically significant. Heterogeneity was quantified with the $I^{2}$ metric $\left(I^{2}=(Q-d f) / Q\right)$, which is independent of the number of studies in the meta-analysis. $\mathrm{I}^{2}$ takes values of between 0 and $100 \%$, with higher values denoting a greater degree of heterogeneity (Zintzaras and Hadjigeorgiou,2005; Zintzaras, 2007). The pooled OR was estimated using fixed effect (FE) (Mantel and Haenszel,1959) and random effect (RE)( DerSimonian and Laird,1986) models. Random effect modeling assumes a genuine diversity in the results of various studies, and it incorporates a between-study variance into the calculations. Hence, when there is heterogeneity between studies then the pooled OR is preferably estimated using the RE model (Whitehead ,2002; Zintzaras, 2007). Genetic models were chosen based on the method described by Thakkinstian et al.(2005), briefly calculating and comparing the ORs of $\mathrm{C}$ vs A (allele contrast), CC vs. AA (homozygote), AC vs. AA (co-dominant) and CC+AC vs. AA (dominant) and $\mathrm{CC}$ vs. AC+AA (recessive), checking the heterogeneity and significance, then determining the best model (Zhang et al.,2013). The Hardy-Weinberg equilibrium of genotypes of controls was tested and if $\mathrm{P}>0$. 05, then it suggest that the controls followed the Hardy-Weinberg equilibrium (HWE) balance.

\section{Publication bias:}

Egger's test (Egger et al.,1997) and Begg's test (Begg and Mazumdar,1994) described for funnel plot asymmetry were applied to evaluate the evidence for publication bias. All $\mathrm{p}$ values are two tailed with a significance level at 0.05 . All statistical analyses were undertaken by MIX version 1.7(Bax et al.,2006).

\section{Results:}

\section{Characteristics of included studies:}

Information extracted from the studies included in the meta-analysis is provided in tables 1 and 2. Total 78 articles were retrieved using search strategies, but 57 articles did not meet the inclusion 
criteria after reviewing full articles. Out of remaining twenty one articles, ten studies were also excluded because reported only C677T polymorphism details (Figure 1). Eleven articles were suitable for the inclusion in the meta-analysis (Shen et al.,2001; Siemianowicz et al.,2003; Shen et al.,2005; Shi et al.,2005; Zhang et al.,2005; Hung et al.,2007; Suzuki et al.,2007; Liu et al.,2009; Arslan et al.,2010; Kiyohara et al.,2011; Ozen et al., 2013)(Table 1). Out of eleven studies five studies were from Asian population(Shen et al.,2005; Zhang et al.,2005; Suzuki et al.,2007; Liu et al.,2009; Kiyohara et al.,2011) and remaining studies were from Caucasian population (Shen et al.,2001; Siemianowicz et al.,2003; Shi et al.,2005; Hung et al.,2007; Arslan et al.,2010; Ozen et al., 2013).

Overall, eleven studies provided 5,996/7404 cases/controls for MTHFR A1298C polymorphism with AA $(3,110), \mathrm{AC}(2,388)$ and $\mathrm{CC}(498)$ genotypes in cases, and with AA $(3,828), \mathrm{AC}(3,024)$, and CC (552) genotypes in controls. In total cases, genotype percentage of $\mathrm{AA}, \mathrm{AC}$, and $\mathrm{CC}$ was $51.67 \%$, $38.83 \%$ and $8.30 \%$ respectively. In controls genotypes, percentage of AA, AC and CC were $51.70 \%$, $40.84 \%$, and $7.45 \%$ respectively. The frequencies of the genotypes AA and AC were the highest in both cases and controls, and allele A was the most common (Table 2). In all the studies, distribution of genotypes in the control group was in Hardy Weinberg Equilibrium.

\section{Meta-analysis:}

Meta-analysis with allele contrast (C vs A) showed no significant association with both fixed effect $\left(\mathrm{OR}_{\mathrm{C} \text { vs A }}=0.99 ; 95 \% \mathrm{CI}=0.93-1.04 ; \mathrm{p}=0.062 ; \mathrm{P}_{\mathrm{Pb}}=0.44\right)$ and random effect model $\left(\mathrm{OR} \mathrm{C}_{\text {vs } \mathrm{A}}=0.95\right.$; 95\% CI= 0.83-1.08; $\mathrm{p}=0.44$ ) (Table 3, Figure 2).

Table 3 summarizes the ORs with corresponding 95\% CIs for association between mutant A1298C polymorphism and risk of lung cancer in homozygote, co-dominant, dominant, and recessive models. Genotype meta-analysis did not report any association with lung cancer (CC vs AA (homozygote model): $\mathrm{OR}_{\mathrm{CC} \text { vs } \mathrm{AA}}=1.13,95 \% \mathrm{CI}=0.83-1.5, \mathrm{p}=0.42$ (Figure 3); AC vs. AA (co-dominant model): $\mathrm{OR}_{\mathrm{AC} \text { vs } \mathrm{AA}}=0.86,95 \% \mathrm{CI}=0.70-1.02, \mathrm{p}=0.90 ; \mathrm{CC}+\mathrm{AC}$ vs. $\mathrm{AA}$ (dominant model): $\mathrm{OR} \mathrm{RC}_{\mathrm{AC}}$ vs $\mathrm{AA}=$ $0.89,95 \% \mathrm{CI}=0.75-1.05, \mathrm{p}=0.19 ; \mathrm{CC}$ vs $\mathrm{AC}+\mathrm{AA}$ (recessive model): $\mathrm{OR}_{\mathrm{CC} \text { vs } \mathrm{AC}+\mathrm{AA}}=1.2,95 \% \mathrm{CI}=$ $0.89-1.4, \mathrm{p}=0.27$ (Figure 4)) .

A true heterogeneity existed between studies for allele contrast $\left(\mathrm{P}_{\text {heterogeneity }}<0.0001, \mathrm{Q}=40.19\right.$, $\left.\mathrm{I}^{2}=67.22 \%, \mathrm{t}^{2}=0.030, \mathrm{z}=0.78\right)$ and genotype homozygote $\left(\mathrm{P}_{\text {heterogeneity }}=0.002, \mathrm{Q}=27.83, \mathrm{I}^{2}=64.07 \%\right.$, $\left.\mathrm{t}^{2}=0.12, \mathrm{z}=0.79\right)$, dominant $\left(\mathrm{P}_{\text {heterogeneity }}<0.0001, \mathrm{Q}=40.08, \mathrm{I}^{2}=75.05 \%, \mathrm{t}^{2}=0.05, \mathrm{z}=1.30\right)$ and recessive $\left(\mathrm{P}_{\text {heterogeneity }}=0.02, \mathrm{Q}=21.44, \mathrm{I}^{2}=53.36 \%, \mathrm{t}^{2}=0.07, \mathrm{z}=1.1\right)$ comparisons. The ' $\mathrm{I}^{2}$ ' value of more than $50 \%$ for between studies comparison in both allele and genotype analysis shows high level of true heterogeneity.

\section{Publication bias:}

Funnel plots using standard error and precision values for allele and genotypes using random effect model were generated (Figure 5). Symmetrical distribution of studies in the funnel plots suggests absence of publication bias. This is also supported by Beggs and Eggers test (Begg's p= 0.24, Egger's $\mathrm{p}=0.44$ for $\mathrm{C}$ vs. A; Begg's $\mathrm{p}=0.75$, Egger's $\mathrm{p}=0.51$ for $\mathrm{CC}$ vs AA; and Begg's $\mathrm{p}=0.07$, Egger's $\mathrm{p}=$ 0.13 for $\mathrm{AC}$ vs. AA; Begg's $\mathrm{p}=0.19$, Egger's $\mathrm{p}=0.23$ for $\mathrm{CC}+\mathrm{AC}$ vs. AA; Begg's $\mathrm{p}=0.63$, Egger's $\mathrm{p}=$ 0.25 for CC vs. AC+AA) (Table 3).

\section{Discussion:}

MTHFR plays a central role in balancing DNA synthesis (which involves 5,10methylentetrahydrofolate) and DNA methylation (which involves 5,10-methyltetrahydrofolate). Specifically, the 677T allele contributes to DNA hypomethylation, which in turn may lead to altered gene expression; at the same time, this polymorphism might exert a protective effect, as observed for colorectal cancer (Botto and Yang, 2000), by increasing the levels of the MTHFR substrate, essential for DNA synthesis. Folate deficiency and metabolism disorders may cause DNA hypomethylation, and A to $\mathrm{C}$ substitution at nucleotide 1298 in MTHFR, which alters enzyme activity, affecting DNA methylation or DNA synthesis, thereby increasing susceptibility to cancer (Umar et al.,2010; Ekiz et al.,2012; Tan et al.,2013). Present meta-analysis included eleven studies with a total of 5,996 cases and 7,404 controls have investigated the association between A1298C polymorphism with lung cancer. 
Meta-analysis is a powerful tool for analyzing cumulative data of studies wherein the individual sample sizes are small and the disease can be easily masked by other genetic and environmental factors (Liang et al.,2013). A meta-analysis potentially investigates a large number of individuals and can estimate the effect of a genetic factor on the risk of the disease (Liang et al., 2013). Several meatanalyses were published to asses effect of folate pathway genes polymorphism as risk for several diseases like- MTHFR prevalence (Yadav et al., 2017),breast cancer (Rai,2014; Kumar et al., 2015; Rai et al., 2017), Ovary cancer (Rai,2016), prostate cancer (Yadav et al.,2016), colorectal cancer (Rai,2015), glucose-6 phosphate dehydrogenase deficiency (Kumar et al.,20016), recurrent pregnancy loss (Rai,2016), hyperurecemia (Rai,2016), Down syndrome (Rai,2011; Rai et al.,2017; Rai and Kumar, 2018), cleft lip/palate (Rai,2014,2017), NTD (Yadav et al., 2015), epilepsy (Rai and Kumar, 2018), schizophrenia (Yadav et al.,2016; Rai et al.,2017), autism (Rai, 2016; Rai and Kumar,2018), depression (Rai,2014), Alzheimers disease (Rai,2016), male infertility (Rai and Kumar,2017), prostate cancer (Yadav et al., 2016), uterine leiomyioma (Kumar and Rai,2018),digestive tract cancer (Yadav et al., 2018), endometrial cancer (Kumar et al., 2018) and esophageal cancer (Kumar and Rai,2018) etc.

Limitations: (i) sample size in few studies were small, (ii)controls were not uniform in all studies ,in some studies hospital based patients of other diseases were considered, (iii) other important factors like smoking and folate intake were not considered in the present meta-analysis and (iv) present review is restricted only one folate pathway gene polymorphism. Further the main strength of the present metaanalysis is absence of publication bias and larger pooled sample size. Present meta-analysis suggested that A1298C polymorphism did not play any role in the etiology of lung cancer.

\section{Conflict of Interest: None References:}

Arslan S, Karadayi S, Yildirim ME, Ozdemir O, Akkurt I. The association between methylenetetrahydrofolate reductase gene polymorphism and lung cancer risk. Mol Biol Rep 2010; 38: 991996.

Bax L, Yu LM, Ikeda N, Tsuruta H, Moons KG. Development and validation of MIX: comprehensive free software for meta-analysis of causal research data. BMC Med. Res. Methodol. 2006;6: 50-54.

Begg CB, Mazumdar M. Operating characteristics of a rank correlation test for publication bias. Biometrics 1994; 50: 1088-1101.

Botto LD, Yang Q. 5,10-Methylenetetrahydrofolate reductase gene variants and congenital anomalies: a HuGE review. Am J Epidemiol 2000;151: 862 - 877.

Cochran WG. The combination of estimates from different experiments. Biometrics 1954; 10: 101 129.

Cui LH, Shin MH, Kim HN, Song HR, Piao JM, Kweon SS, et al. Methylenetetrahydrofolate reductase $\mathrm{C} 677 \mathrm{~T}$ polymorphism in patients with lung cancer in a Korean population. BMC Med Genet 2011; 12:28-33.

DerSimonian R, Laird N. Meta-analysis in clinical trials. Controlled Clinical Trials 1986; 7: 17788.

Egger M, Davey Smith G, Schneider M, Minder C. Bias in meta-analysis detected by a simple, graphical test. BMJ 1997; 315: 629-634. 
medRxiv preprint doi: https://doi.org/10.1101/19011593; this version posted November 14, 2019. The copyright holder for this preprint (which was not certified by peer review) is the author/funder, who has granted medRxiv a license to display the preprint in perpetuity. It is made available under a CC-BY-ND 4.0 International license .

Ekiz F, Ormeci N, Coban S, Karabulut HG, Aktas B, Tukun A, et al. Association of methylenetetrahydrofolate reductase C677T-A1298C polymorphisms with risk for esophageal adenocarcinoma, Barrett's esophagus, and reflux esophagitis. Dis Esophagus 2012; 25, 437-41.

Ferlay J, Shin HR, Bray F, Forman D, Mathers C, Parkin DM. Estimates of worldwide burden of cancer in 2008: GLOBOCAN 2008. Int J Cancer 2010; 127: 2893-2917.

Frosst P, Bloom HJ, Milos R, Goyette P, Sheppard CA, Mathews RG et al. A Candidate Genetic Risk Factor for Vascular Disease: a Common Mutation in Methylenetetrahydrofolate Reductase Nat Genet 1995;10: 111-113.

Hung RJ, Hashibe M, McKay J, Gaborieau V, Szeszenia-Dabrowska N, Zaridze D, et al. Folaterelated genes and the risk of tobacco-related cancers in Central Europe. Carcinogenesis 2007; 28:1334-1340.

Jemal A, Siegel R, Ward E, Murray T, Xu J, Thun MJ. Cancer statistics, 2007. Cancer J Clin 2007; 57: 43-66.

Kiyohara C, Horiuchi T, Takayama K, Nakanishi Y. Methylenetetrahydrofolate reductase polymorphisms and interaction with smoking and alcohol consumption in lung cancer risk: a casecontrol study in a Japanese population. BMC Cancer 2011; 11: 459-466.

Kumar P, Yadav U, Rai V, Methylenetetrahydrofolate reductase gene C677T polymorphism and breast cancer risk: Evidence for genetic susceptibility. Meta

Gene 2015; $6: 72-84$.

Kumar P, Yadav U, Rai V. Prevalence of glucose-6-phosphate dehydrogenase deficiency in India: An updated meta-analysis. Egypt J Med Hum Genet 17 (3), 295-302.

Kumar P, Rai V. Methylenetetrahydrofolate reductase C677T polymorphism and risk of esophageal cancer: An updated meta-analysis. Egypt J Med Hum Genet. 2018; 19(4): 273-284.

Kumar P, Rai V.2018. Catechol-O-Methyltransferase Val158Met polymorphism and susceptibility to Uterine Leiomyoma. Jacobs Journal of Gynecology and Obstetrics. 2018;5(1): 043.

Kumar, P., Singh, G., Rai, V. 2018. Evaluation of COMT gene rs4680 polymorphism as a risk factor for endometrial cancer. IJCB ,2018c; 10.1007/s12291-018-0799-x.

Liang H, Yan Y, Li T, Li R, Li M, Li S, Qin X. Methylenetetrahydrofolate reductase polymorphisms and breast cancer risk in Chinese population: a meta-analysis of 22 case-control studies. Tumor Biol. 2013; 1007/s13277-013-1234-9.

Liu CS, Tsai CW, Hsia TEC, Wang RF, Liu CJ, Hang LW, et al. Interaction of methylenetetrahydrofolate reductase genotype and smoking habit in Taiwanese lung cancer patients. Cancer Genomics Proteomics 2009; 6: 325-329.

Mantel N, Haenszel W. Statistical aspects of the analysis of data from retrospective studies of disease. J Natl Cancer Inst 1959; 22: 719-748. 
medRxiv preprint doi: https://doi.org/10.1101/19011593; this version posted November 14, 2019. The copyright holder for this preprint (which was not certified by peer review) is the author/funder, who has granted medRxiv a license to display the preprint in perpetuity. It is made available under a CC-BY-ND 4.0 International license.

Ozen F, Polat F, Arslan S, Ozdemir O. Combined Germline Variations of Thrombophilic Genes Promote Genesis of Lung Cancer. Asian Pac J Cancer Prev 2013; 14: 5449-5454 .

Parkin DM, Bray F, Ferlay J, Pisani P. Global cancer statistics, 2002. Cancer J Clin 2002; 55: 74108.

Rai V, Yadav U, Kumar P, Yadav SK .2010. Methyleletetrahydrofolate reductase polymorphism (C677T) in Muslim population of Eastern Uttar Pradesh, India. Ind J Med Sci 64: 219-223.

Rai V, Yadav U, Kumar P. 2012. Genotype Prevalence and Allele Frequencies of 5,10Methylenetetrahydrofolate Reductase (MTHFR) C677T Mutation in two Caste Groups of India. Cell Mol Biol 58: OL1695- 701.

Rai V. Polymorphism in folate metabolic pathway gene as maternal risk factor for Down syndrome. Int J Biol Med Res. 2011; 2(4): 1055-1060.

Rai V. Methylenetetrahydrofolate Reductase A1298C Polymorphism and Breast Cancer Risk: A Meta-analysis of 33 Studies. Ann Med Health Sci Res. 2014; 4(6): 841-851.

Rai V. Genetic polymorphisms of methylenetetrahydrofolate reductase (MTHFR) gene and susceptibility to depression in Asian population: a systematic meta-analysis. Cell Mol Biol. 2014; 60 (3): 29-36.

Rai V. Maternal methylenetetrahydrofolate reductase (MTHFR) gene A1298C polymorphism and risk of nonsyndromic Cleft lip and/or Palate (NSCL/P) in offspring: A meta-analysis. Asian J Med Sci. 2014; 6 (1): 16- 21.

Rai V. Evaluation of the MTHFR C677T Polymorphism as a Risk Factor for Colorectal Cancer in Asian Populations. Asian Pac J Cancer Prev. 2015; 16 (18): 8093-8100.

Rai V (2016) Folate pathway gene methylenetetrahydrofolate reductase C677T polymorphism and Alzheimer disease risk in Asian population. Ind J Clin Biochem 31(3):245-52.

Rai V (2016d) The MTHFR C677T polymorphism and hyperuricemia Risk: a meta-analysis of 558 cases and 912 controls. Metabolomics 6: doi.org/10.4172/2153-0769.1000166.

Rai V. Association of methylenetetrahydrofolate reductase (MTHFR) gene C677T polymorphism with autism: evidence of genetic susceptibility. Metab Brain Disease 2016; 31: 727-735.

Rai V. Methylenetetrahydrofolate reductase C677T polymorphism and recurrent pregnancy loss risk in Asian population: a meta-analysis. Ind J Clin Biochem. 2016; 31: 402-13.

Rai V. Methylenetetrahydrofolate Reductase Gene C677T Polymorphism and Its Association with Ovary Cancer. J Health Med Informat. 2016; 7: 3-9.

Rai V, Yadva U, Kumar P. Null association of maternal MTHFR A1298C polymorphism with Down syndrome pregnancy: An updated meta-analysis. Egyptian J Med Hum Genet. 2017; 18(1): 9-18.

Rai V. Strong association of C677T polymorphism of ethylenetetrahydrofolate reductase gene with nosyndromic cleft lip/palate (nsCL/P). Ind J Clin Biochem. 2017; 2: 1-11. 
medRxiv preprint doi: https://doi.org/10.1101/19011593; this version posted November 14, 2019. The copyright holder for this preprint (which was not certified by peer review) is the author/funder, who has granted medRxiv a license to display the preprint in perpetuity. It is made available under a CC-BY-ND 4.0 International license .

Rai V, Kumar P. Methylenetetrahydrofolate reductase C677T polymorphism and risk of male infertility in Asian population. Ind J Clin Biochem. 2017; 32(3): 253-26.

Rai V, Yadav U, Kumar P, Yadav SK, Gupat S. Methylenetetrahydrofolate reductase A1298C genetic variant \& risk of schizophrenia: A meta-analysis. In J Med Res. 2017;145:437- 442.

Rai V, Yadav U, Kumar P. Impact of catechol-O-methyltransferase Val 158Met (rs4680) polymorphism on breast cancer susceptibility in Asian population. Asian Pac J Cancer Prev. 2017; 18(5):1243-50.

Rai V, Kumar P. Fetal MTHFR C677T polymorphism confers no susceptibility to Down Syndrome: evidence from meta-analysis. Egyptian J Med Hum Genet. 2018; 19: 53-58.

Rai V, Kumar P (2018) Methylenetetrahydrofolate reductase A1298C polymorphism and autism susceptibility. Austin Journal of Autism \& Related Disabilities 4: 1048-1053.

Rai, V., Kumar, P. 2018. Methylenetetrahydrofolate reductase C677T polymorphism and susceptibility to epilepsy. Neurol Sci. 2018d; 10.1007/s10072-018-3583-z.

Robien K, Ulrich CM. 5,10- Methylenetetrahydrofolate reductase polymorphisms and leukemia risk: a HuGE minireview. Am J Epidemiol 2003; 157:571-82.

Shen H, Spitz MR, Wang LE, Hong WK, Wei Q. Polymorphisms of methylene-tetrahydrofolate reductase and risk of lung cancer: a case-control study. Cancer Epidemiol Biomarkers Prev 2001; 10:397-401.

Shen M, Rothman N, Berndt SI, He X, Yeager M, Welch R, et al. Polymorphisms in folate metabolic genes and lung cancer risk in Xuan Wei, China. Lung Cancer 2005; 49: 299-309.

Shi Q, Zhang Z, Li G, Pillow PC, Hernandez LM, Spitz MR, Wei Q. Sex differences in risk of lung cancer associated with methylene-tetrahydrofolate reductase polymorphisms. Cancer Epidemiol Biomarkers Prev 2005; 14: 1477-1484.

Siemianowicz K, Gminski J, Garczorz W, Slabiak N, Goss M, Machalski M, et al. Methylenetetrahydrofolate reductase gene C677T and A1298C polymorphisms in patients with small cell and non-small cell lung cancer. Oncol Rep 2003; 10:1341-1344.

Stroup DF, Berlin JA, Morton SC, Olkin I, Williamson GD, Rennie D, et al. Meta-analysis of observational studies in epidemiology: a proposal for reporting. Meta-analysis Of Observational Studies in Epidemiology (MOOSE) group. JAMA 2000; 283: 2008-2012.

Suzuki T, Matsuo K, Hiraki A, Saito T, Sato S, Yatabe Y, et al. Impact of one-carbon metabolismrelated gene polymorphisms on risk of lung cancer in Japan: a case-control study. Carcinogenesis 2007; 28:1718-1725.

Tan X, Wang YY, Dai L, Liao XQ, Chen MW. Genetic Polymorphism of MTHFR A1298C and Esophageal Cancer Susceptibility: A Meta-analysis. Asian Pac J Cancer Prev 2013; 14: 951-1955 
medRxiv preprint doi: https://doi.org/10.1101/19011593; this version posted November 14, 2019. The copyright holder for this preprint (which was not certified by peer review) is the author/funder, who has granted medRxiv a license to display the preprint in perpetuity. It is made available under a CC-BY-ND 4.0 International license .

Thakkinstian A, McEvoy M, Minelli C, Gibson P, Hancox B, Duffy D et al. Systematic review and meta-analysis of the association between (beta) 2- adrenoceptor polymorphisms and asthma: a HuGE review. Am J Epidemiol 2005; 162: 201-11.

Umar M, Upadhyay R, Khurana R, Kumar S, Ghoshal UC, Mittal B. Evaluation of MTHFR677C $>\mathrm{T}$ polymorphism in prediction and prognosis of esophageal squamous cell carcinoma: a case-control study in a northern Indian population. Nutr Cancer 2010; 62: 743-9.

van der Put NM, Gabreels F, Stevens EM, Smeitink JA, Trijbels FJ, Eskes TK, et al. A second common mutation in the methylenetetrahydrofolate reductase gene: an additional risk factor for neural-tube defects? Am J Hum Genet 1998; 62:1044-1051.

Weisberg I, Tran P, Christensen B, Sibani S, Rozen A. A second genetic polymorphism in methylenetetrahydrofolate reductase (MTHFR) associated with decreased enzyme activity. Mol Genet Metab 1998; 64:169-72.

Whitehead A . Meta-analysis of controlled clinical trials. Wiley, Chichester, UK 2002.

Yadav U, Kumar P, Yadav SK, Mishra OP, Rai V . Polymorphisms in folate metabolism genes as maternal risk factor for neural tube defects: an updated meta-analysis. Metabolic brain disease 30 (1), 7-24.

Yadav U, Kumar P, Gupta S, Rai V. Role of MTHFR C677T gene polymorphism in the susceptibility of schizophrenia: An updated meta-analysis. Asian J Psychiatry 2016; 20: 41-51 .

Yadav U, Kumar P, Rai V. Role of MTHFR A1298C gene polymorphism in the etiology of prostate cancer: a systematic review and updated meta-analysis. Egyp J Med Hum Genet 2016; 17: 141-148.

Yadav U, Kumar P, Gupta S, Rai V. Distribution of MTHFR C677T gene polymorphism in healthy North Indian population and an updated meta-analysis. Ind J Clinical Biochem 2017; 32(4):399-410.

Yadav U, Kumar P, Rai V. NQO1 gene C609T polymorphism (dbSNP: rs1800566) and digestive tract cancer risk: A Meta analysis. Nutrition and Cancer. 2018; 10.1080/01635581.20

Zhang T, Lou J, Zhong R, Wu J, Zou L, SunY, et al. Genetic Variants in the Folate Pathway and the Risk of Neural Tube Defects: A Meta-Analysis of the Published Literature. PLos one 2013; 8: e59570.

Zhang XM, Miao XP, Tan W, Qu SN, Sun T, Zhou YF, Lin DX. Association between genetic polymorphisms in methylenetetrahydrofolate reductase and risk of lung cancer. Acta Academiae Medicinae Sinicae. 2005; 27:700-703.

Zintzaras E, Hadjigeorgiou GM. The role of G196A polymorphism in the brain-derived neurotrophic factor gene in the cause of Parkinson's disease: a meta-analysis. J Hum Genet 2005; 50:560-566.

Zintzaras E. Maternal gene polymorphisms involved in folate metabolism and risk of Down syndrome offspring: a meta-analysis. J Hum Gene 2007; 52:943-53. 
medRxiv preprint doi: https://doi.org/10.1101/19011593; this version posted November 14, 2019. The copyright holder for this preprint (which was not certified by peer review) is the author/funder, who has granted medRxiv a license to display the preprint in perpetuity.

It is made available under a CC-BY-ND 4.0 International license.

Table 1. Characteristics of eleven studies included in the present meta-analysis

\begin{tabular}{|c|c|c|c|c|}
\hline Study & Ethnicity & $\begin{array}{l}\text { Cont } \\
\text { rol }\end{array}$ & Case & Reference \\
\hline Shen et al.,2001 & $\begin{array}{l}\text { Non-Hispanic } \\
\text { White }\end{array}$ & 554 & 550 & $\begin{array}{l}\text { Can Epidemiol Biomarkers Prev 10:397- } \\
401 \text {. }\end{array}$ \\
\hline $\begin{array}{l}\text { Siemianowicz et } \\
\text { al.,2003 }\end{array}$ & Europen & 44 & 146 & Oncol Rep, 10: 1341-4. \\
\hline Shen et al.,2005 & Asian & 49 & 114 & Lung Cnacer,49:299-309. \\
\hline Shi et al.,2005 & $\begin{array}{l}\text { Non-Hispanic } \\
\text { White }\end{array}$ & 1141 & 1051 & $\begin{array}{l}\text { Can Epidemiol Biomarkers Prev } \\
14: 1477-84 \text {. }\end{array}$ \\
\hline Zhang et al.,2005 & Asian & 400 & 505 & Acta Acad Med Sin 27:700-703. \\
\hline Hung et al.,2007 & Europen & 2865 & 2209 & Carcinogenesis 28:1334-1340 \\
\hline Suzuki et al.,2007 & Asian & 1019 & 485 & Carcinogenesis 28:1718-1725. \\
\hline Liu et al.,2009 & Asian & 716 & 358 & Can. Geno \& Proteo 6: 325-330. \\
\hline Arslan et al.,2011 & Europen & 61 & 64 & Mol Biol Rep (2011) 38:991-996 \\
\hline Kiyoaha et al.,2011 & Asian & 379 & 462 & BMC Cancer 2011, 11:459 \\
\hline Ozen et al.,2013 & European & 176 & 52 & $\begin{array}{l}\text { Asian Pac J Cancer Prev, } 14 \text { (9):5449- } \\
5454\end{array}$ \\
\hline
\end{tabular}

Table 2. The distributions of MTHFR A1298C genotypes and alleles number for lung cancer cases and controls

\begin{tabular}{|l|r|r|r|r|r|r|r|r|r|r|}
\hline & \multicolumn{4}{|c|}{ Genotype } & \multicolumn{4}{c|}{ Alleles } \\
\cline { 2 - 12 } & \multicolumn{2}{|c|}{ AA } & \multicolumn{2}{|c|}{ AC } & \multicolumn{2}{|c|}{ CC } & \multicolumn{3}{|c|}{ A } & \multicolumn{1}{c|}{ C } \\
\cline { 2 - 11 } Study ID & Case & Control & Case & Control & Case & Control & Case & Control & Case & Con \\
\hline Shen,2001 & 261 & 265 & 246 & 249 & 43 & 40 & 768 & 779 & 332 & \\
\hline
\end{tabular}


medRxiv preprint doi: https://doi.org/10.1101/19011593; this version posted November 14, 2019. The copyright holder for this preprint (which was not certified by peer review) is the author/funder, who has granted medRxiv a license to display the preprint in perpetuity.

It is made available under a CC-BY-ND 4.0 International license .

\begin{tabular}{|l|r|r|r|r|r|r|r|r|r|r|}
\hline Siemianowicz,2003 & 32 & 12 & 76 & 24 & 38 & 8 & 140 & 48 & 152 & \\
\hline Shen,2005 & 71 & 9 & 41 & 34 & 2 & 6 & 183 & 52 & 45 & \\
\hline Shi,2005 & 480 & 554 & 462 & 496 & 109 & 91 & 1422 & 1604 & 680 & \\
\hline Zhang,2005 & 355 & 245 & 141 & 150 & 9 & 5 & 851 & 640 & 159 & \\
\hline Hung,2007 & 1031 & 1285 & 960 & 1268 & 218 & 312 & 3022 & 3838 & 1396 & 1 \\
\hline Suzuki,2007 & 314 & 652 & 149 & 322 & 22 & 45 & 777 & 1626 & 193 & \\
\hline Liu,2009 & 228 & 467 & 115 & 226 & 15 & 23 & 571 & 1160 & 145 & 41 \\
\hline Arslan,2011 & 29 & 28 & 29 & 29 & 6 & 4 & 87 & 85 & 41 & 214 \\
\hline Kiyoaha,2011 & 278 & 239 & 154 & 122 & 30 & 18 & 710 & 600 & 214 \\
\hline Ozen,2013 & 31 & 72 & 15 & 104 & 6 & 0 & 77 & 248 & 27 & \\
\hline
\end{tabular}

Table: 3: Summary estimates for the odds ratio (OR) of MTHFR A1298C in various allele/genotype contrasts, $95 \%$ confidence limits, the significance level, $p$ value of heterogeneity test ( $Q$ test), and the $I^{2}$ metric, and publication bias p-value (Egger Test).

\begin{tabular}{|c|c|c|c|c|c|c|}
\hline Genetic Models & $\begin{array}{l}\text { Fixed effect } \\
\text { OR }(95 \% \mathrm{CI}), \mathbf{p} \\
\text { value }\end{array}$ & $\begin{array}{l}\text { Random effect } \\
\text { OR }(95 \% \text { CI }), p \\
\text { value }\end{array}$ & $\begin{array}{l}\text { Heter } \\
\text { ogene } \\
\text { ity p- } \\
\text { value } \\
\text { (Q } \\
\text { test) }\end{array}$ & $\begin{array}{l}\mathbf{I}^{2} \\
(\%)\end{array}$ & $\begin{array}{l}\text { Publicatio } \\
\text { n bias } \\
\text { (p value of } \\
\text { Begg's } \\
\text { test) }\end{array}$ & $\begin{array}{l}\text { Publicatio } \\
\text { n bias (p } \\
\text { of Egger's } \\
\text { test) }\end{array}$ \\
\hline Additive (C vs A) & $\begin{array}{l}0.99(0.93- \\
1.04), 0.62\end{array}$ & $\begin{array}{l}0.95(0.83- \\
1.08), 0.44\end{array}$ & $\begin{array}{l}<0.00 \\
01\end{array}$ & $\begin{array}{l}75.1 \\
2\end{array}$ & 0.24 & 0.44 \\
\hline $\begin{array}{l}\text { Co-dominant (AC } \\
\text { vs AA) }\end{array}$ & $\begin{array}{l}0.94(0.87- \\
1.0), 0.07\end{array}$ & $0.86(0.7-1.02), 0.9$ & $\begin{array}{l}<0.00 \\
01\end{array}$ & $\begin{array}{l}73.7 \\
7\end{array}$ & 0.07 & 0.13 \\
\hline $\begin{array}{l}\text { Homozygote (CC } \\
\text { vs AA) }\end{array}$ & $1.05(0.92-1.2), 0.5$ & $1.13(0.83-1.5), 0.42$ & 0.002 & $\begin{array}{l}64.0 \\
3\end{array}$ & 0.75 & 0.51 \\
\hline $\begin{array}{l}\text { Dominant } \\
\text { (CC+AC vs AA) }\end{array}$ & $\begin{array}{l}0.95(0.88- \\
1.01), 0.16\end{array}$ & $\begin{array}{l}0.89(0.75- \\
1.05), 0.19\end{array}$ & $\begin{array}{l}<0.00 \\
1\end{array}$ & $\begin{array}{l}75.0 \\
5\end{array}$ & 0.19 & 0.23 \\
\hline $\begin{array}{l}\text { Recessive } \\
(\mathrm{AA}+\mathrm{AC} \text { vs CC) }\end{array}$ & $1.1(0.93-1.2), 0.35$ & $1.2(0.89-1.4), 0.27$ & 0.02 & $\begin{array}{l}53.3 \\
6\end{array}$ & 0.63 & 0.25 \\
\hline
\end{tabular}

Figures: 
medRxiv preprint doi: https://doi.org/10.1101/19011593; this version posted November 14, 2019. The copyright holder for this preprint (which was not certified by peer review) is the author/funder, who has granted medRxiv a license to display the preprint in perpetuity.

It is made available under a CC-BY-ND 4.0 International license .

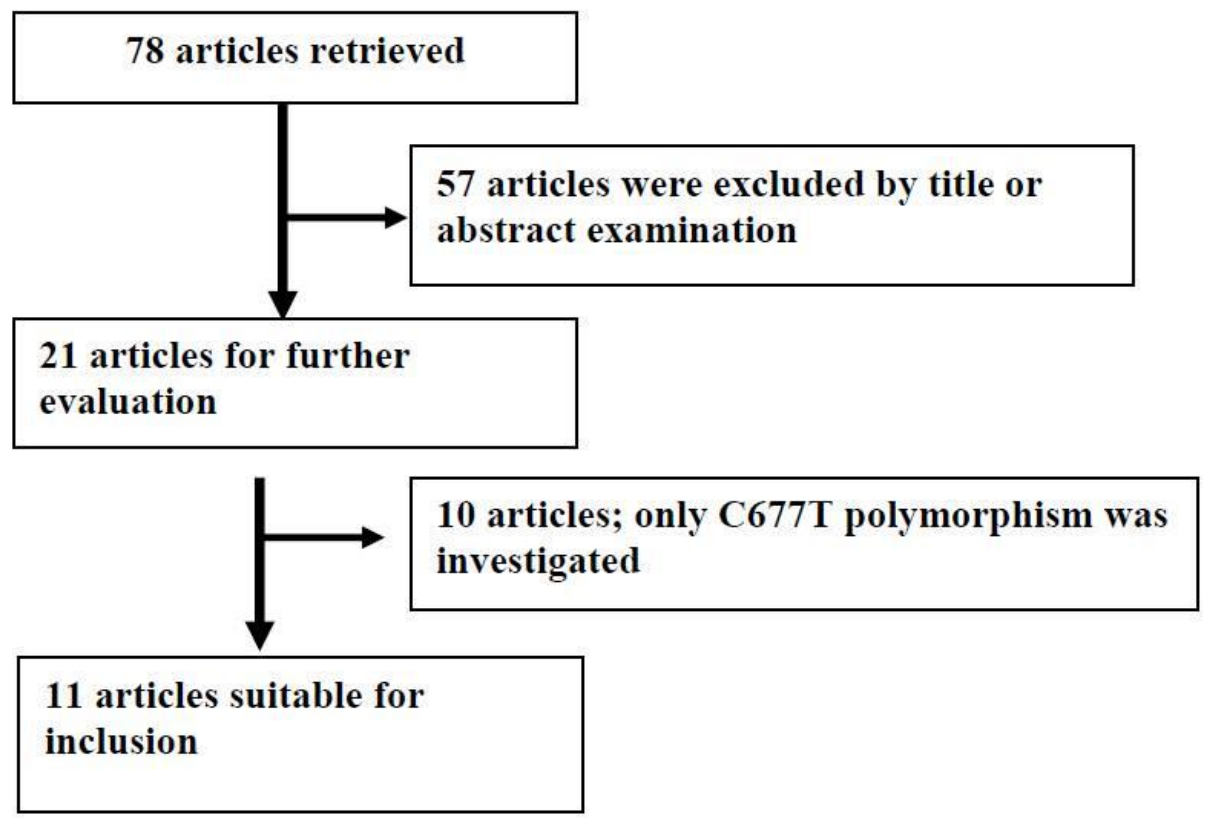

Figure 1. Flow diagram of study selection

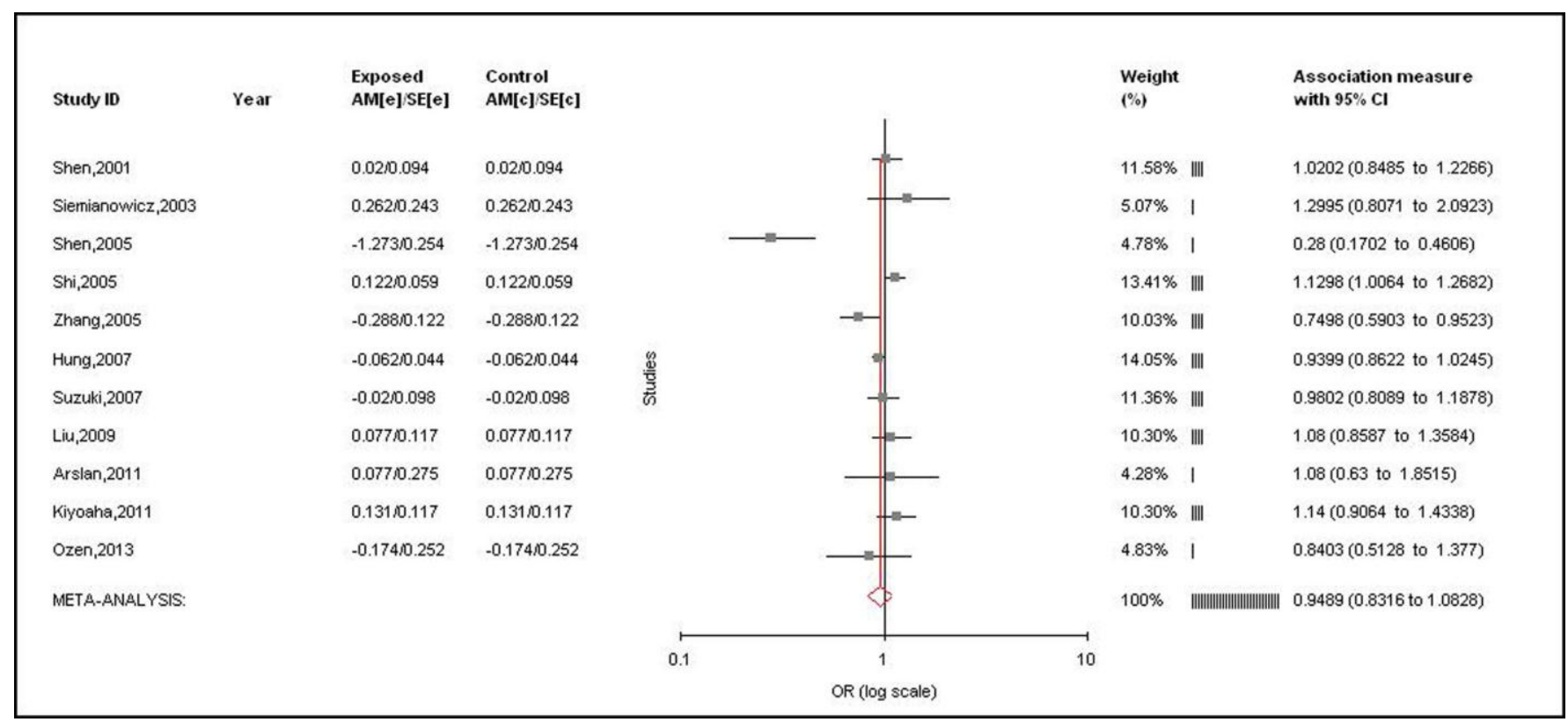

Figure 2. Forest plots for the association between MTHFR A1298C polymorphism and lung cancer for allele contrast model ( $\mathrm{C}$ vs $\mathrm{A})$ with random effect model. 
medRxiv preprint doi: https://doi.org/10.1101/19011593; this version posted November 14, 2019. The copyright holder for this preprint (which was not certified by peer review) is the author/funder, who has granted medRxiv a license to display the preprint in perpetuity.

It is made available under a CC-BY-ND 4.0 International license .

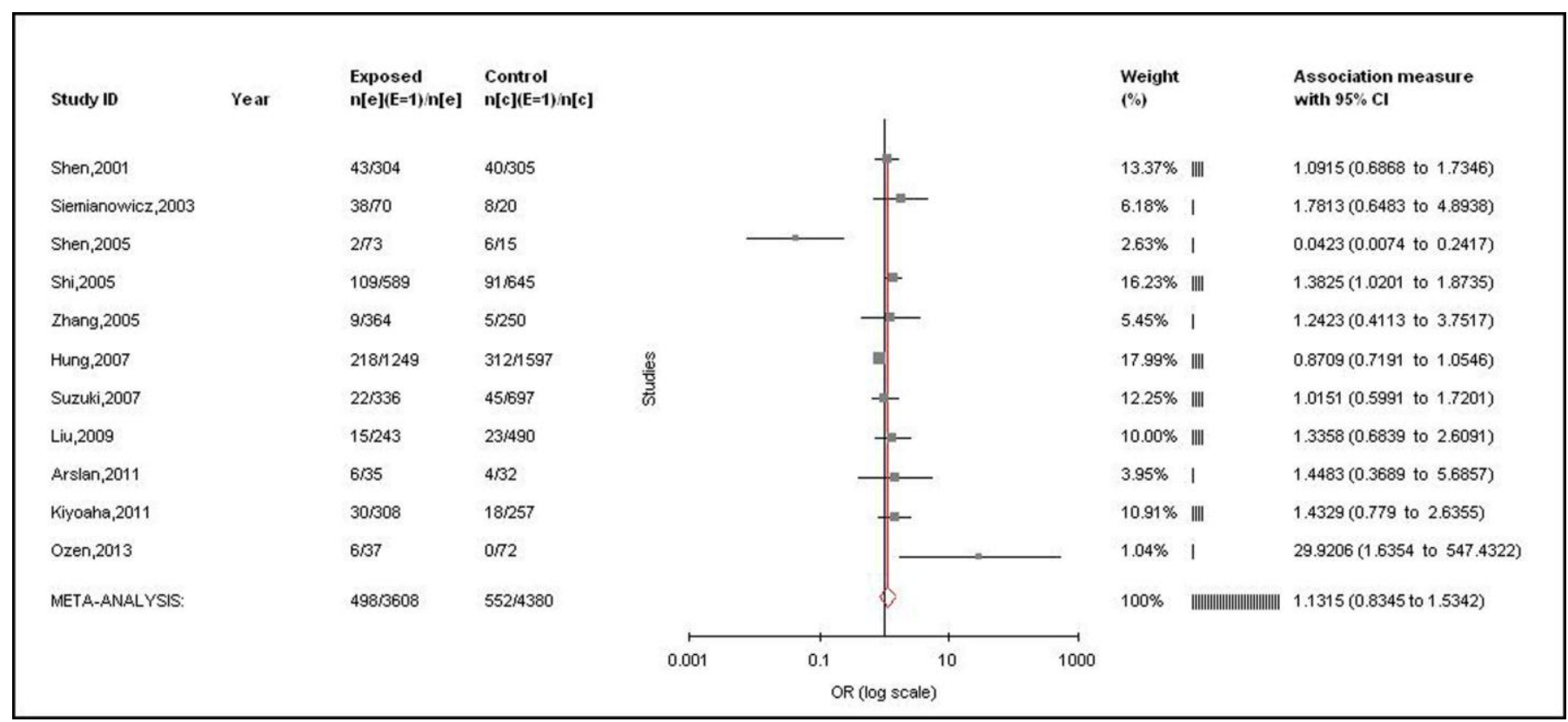

Figure 3. Forest plots for the association between MTHFR A1298C polymorphism and lung cancer for homozygote model (CC vs AA) with random effect model.

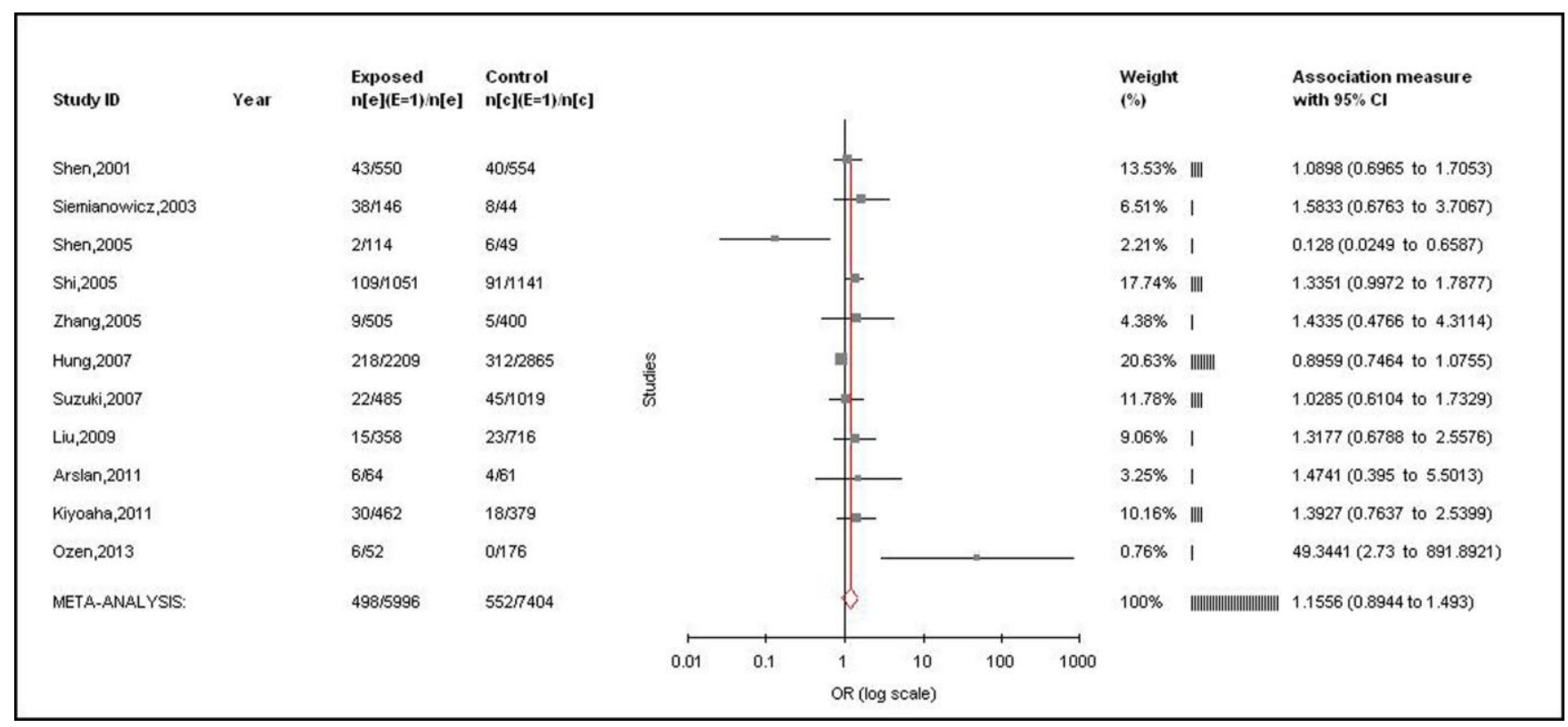

Figure 4. Forest plots for the association between MTHFR A1298C polymorphism and lung cancer for dominant model $(\mathrm{CC}+\mathrm{AC}$ vs AA) with random effect model. 
medRxiv preprint doi: https://doi.org/10.1101/19011593; this version posted November 14, 2019. The copyright holder for this preprint (which was not certified by peer review) is the author/funder, who has granted medRxiv a license to display the preprint in perpetuity. It is made available under a CC-BY-ND 4.0 International license .
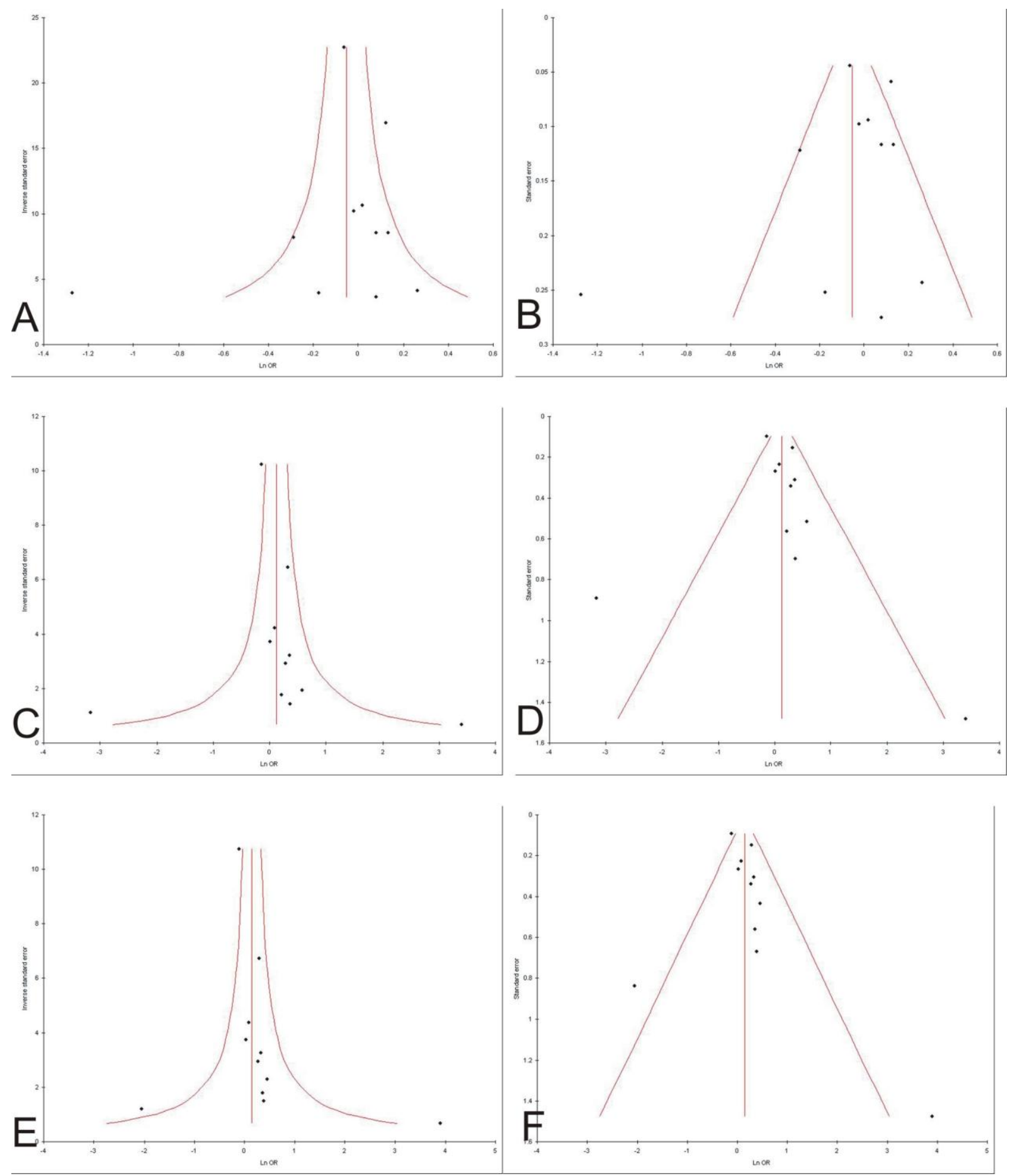

Figure 5. Funnel plots A. precision versus OR (C vs A), B. standard error versus OR (C vs A) C. precision versus $\mathrm{OR}(\mathrm{CC}$ vs $\mathrm{AA})$, D. standard error versus $\mathrm{OR}$ (CC vs AA), E. precision versus OR $(\mathrm{CC}+\mathrm{AC}$ vs $\mathrm{AA}), \mathrm{F}$. standard error versus $\mathrm{OR}(\mathrm{CC}+\mathrm{AC}$ vs $\mathrm{AA})$. 